\title{
THE COMPARATIVE ANALYSIS OF TWO PRE-ROMAN IRON AGE BOG BODIES FROM NORTHWEST GERMANY USING PORTABLE $X$-RAY FLUORESCENCE SPECTROSCOPY
}

\author{
Guinevere Granite ${ }^{1}$, Andreas Bauerochse ${ }^{2}$ \\ ${ }^{1}$ University of Maryland, Baltimore, Maryland, USA \\ ${ }^{2}$ Lower Saxony State Service for Cultural Heritage, Hannover, Germany
}

\begin{abstract}
Portable X-ray Fluorescence Spectroscopy (PXRFS) is a non-destructive testing method that can offer objective, on-site information concerning elemental composition. The objective was to better understand Northern European bog environmental chemistry and its diagenetic effects on interred bog bodies, and identify post-discovery preservation procedures applied to the remains. This article discusses the findings regarding two of thirteen bog bodies we studied: Husbäke Man and Jührdenerfeld Man.

To assess potential bog diagenetic effects, the following elements were analyzed: Copper, Iron, Manganese, Molybdenum, Lead, and Zirconium. The elemental concentrations were also used to assess the application of post-discovery preservation procedures, along with Cobalt, Antimony, and Titanium.

The significantly higher elemental concentrations in all elements of interest suggest that elemental incorporation occurred in the bog. In addition, the readings taken from Jührdenerfeld Man demonstrate exceedingly high elemental values for Cobalt, supporting post-discovery elemental incorporation.

PXRFS provides valuable information about the interactions between the bog environment and bog body remains, and can identify post-discovery preservative treatment implementation. Thus, PXRFS can improve comprehension of archival collection history of bog bodies, and can offer the possibility of reversing or lessening the effects of detrimental preservative treatments to the bog bodies.
\end{abstract}


Keywords: bog bodies; portable XRF spectroscopy; elemental analysis; diagenesis; post-discovery preservation procedures

\section{INTRODUCTION}

Northern Europe bog bodies are distinguished types of archaeological findings (20). Their discoveries continue to inspire scientists worldwide and often lead to the creation of myths and legends regarding their lives and deaths. Therefore, knowledge about their origin, diagenetic effects, and post-discovery treatments are of importance for a better understanding of these findings. Recently, some of the prehistoric bog body findings from Denmark and Germany have been reinvestigated using modern methods. The presented results are part of the research activities on German bog bodies, which are still in progress (e.g. 2, 6, 7-12, 15).

X-Ray Fluorescence Spectroscopy (XRFS) helps to determine and quantify the elemental composition of samples by using X-ray excitation. XRFS rapidly identifies and reliably enumerates elements over an extensive concentration range, while neither destroying nor contaminating the sample tested $(3,4,7$, $8,11-14,18,21,22$ ). Portable (hand-held) XRFS (PXRFS) provides a nondestructive testing method that offers objective, laboratory grade, presumptive analyses on on-site testing samples, such as metal alloys, mineral deposits, soil samples, and bone $(1,4,8-10,14,17)$.

Portable XRFS can provide objective, on-site information regarding environmental understanding of bog body burial sites and its diagenetic effects on the interred bog body. Portable XRFS can also identify whether housing curators and staff applied post-discovery preservation procedures to bog bodies, and to what extent such preservation has affected the bog body remains. This research focused on the application of portable XRFS to both the skeletal remains and the surrounding burial environment of thirteen bog bodies. Two of these bog bodies are known as Husbäke Man and Jührdenerfeld Man. This article summarizes and compares the portable XRFS findings for those individuals (7).

These two bog bodies were chosen because both are raised bog bodies, discovered by farmers, digging peat in the middle 1930s. Both bog bodies have been found in close proximity to one another (Fig. 1) and subsequently, housed at the State Museum Natur und Mensch in Oldenburg, Germany, where they are exhibited. In addition, evidence suggested that Husbäke Man had no received post-discovery preservative treatment, while Jührdenerfeld Man had. 


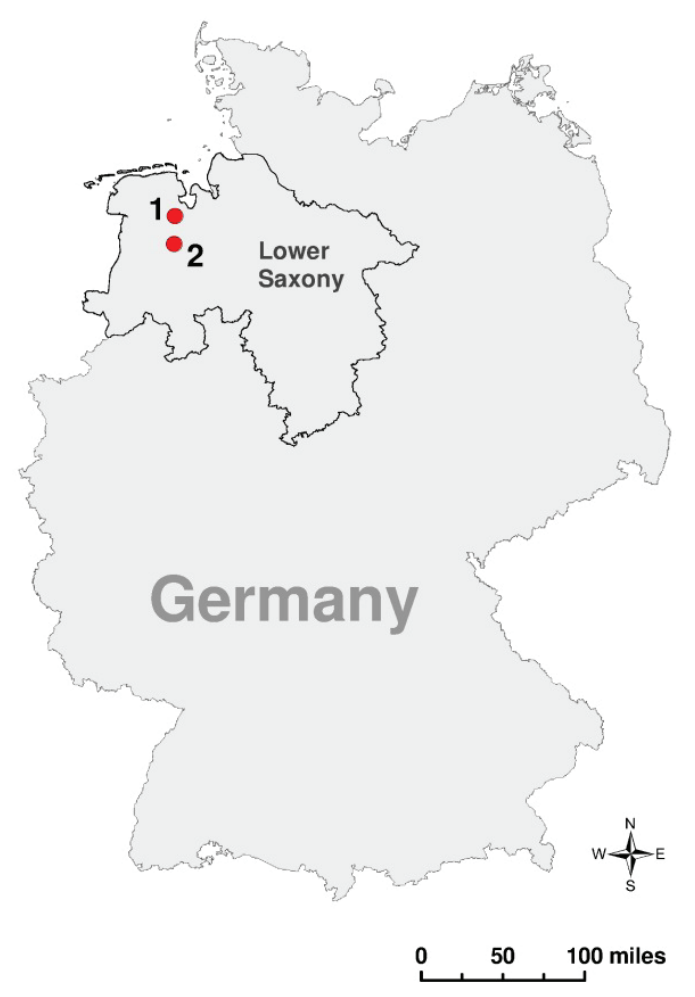

Figure 1. Sitemap for Husbäke Man (1) and Jührdenerfeld Man (2).

\section{Bog Body Background: Husbäke Man}

The remains of Husbäke Man, also known as Husbäke II, were found on October $15^{\text {th }}, 1936$, in the bogs of Vehnemoor (Oldenburg District), Lower Saxony, Germany (5) (Fig. 2). ${ }^{14} \mathrm{C}$-AMS dating for a skin sample from the bog body determined a calibrated date for the remains of 765-520 cal BC in the PreRoman Iron Age (19). Our osteological analysis of the remains found this individual to be a male, either 19 or 20 at the time of his death based on the fusion assessment of long bone epiphyseal-diaphyseal union sites, which corresponded with the examiners estimation of approximately 20 years old (16). We also determined that he was of probable Caucasian ancestry and possible Asian ancestry due to his shovel-shaped incisors, and a stature ranging between $5 \mathrm{ft} 8$ in and 6 $\mathrm{ft} 2$ in. Additional osteological findings can be found in Granite 2012 (7). 


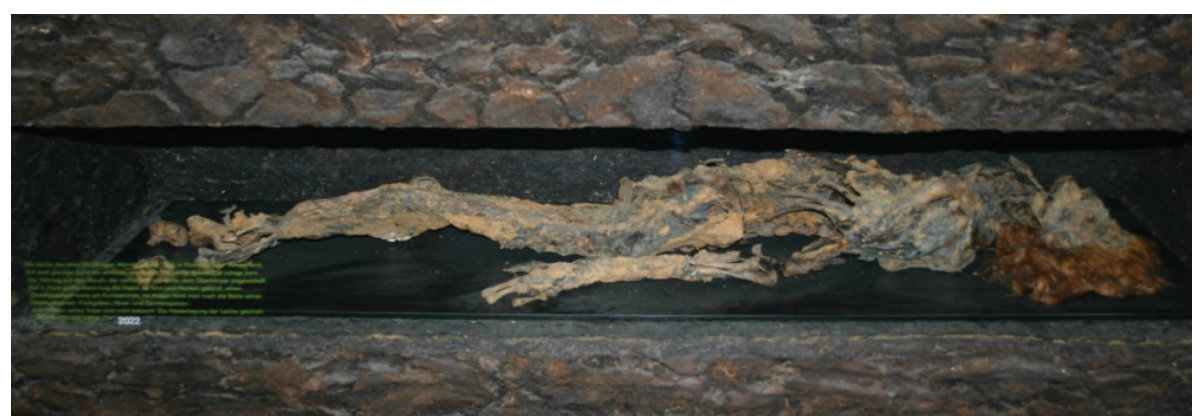

Figure 2. The remains of Husbäke Man.

\section{Bog Body Background: Jührdenerfeld Man}

Jührdenerfeld Man, also known as Bockhornerfeld Man, was discovered on November $19^{\text {th }}, 1934$ in Jührdenerfeld (Friesland District), Lower Saxony, Germany (Fig. 3). Two ${ }^{14} \mathrm{C}$-AMS dating analyses of hair and skin samples from the body resulted in calibrated ranges of $170-45 \mathrm{cal} \mathrm{BC}$ and $40 \mathrm{cal} \mathrm{BC}-\mathrm{AD} 75$ dating also to the Pre-Roman Iron Age $(5,19)$. Analysts determined the age to be around 35 years old (5). During our osteological investigations, we also found him to be of probable Caucasian ancestry with an estimated stature range of approximately $4 \mathrm{ft} 10.5$ in to $5 \mathrm{ft} 3$ in because of the limited amount of present long bones. Additional findings from our osteological analysis can be found in Granite 2012 (7).

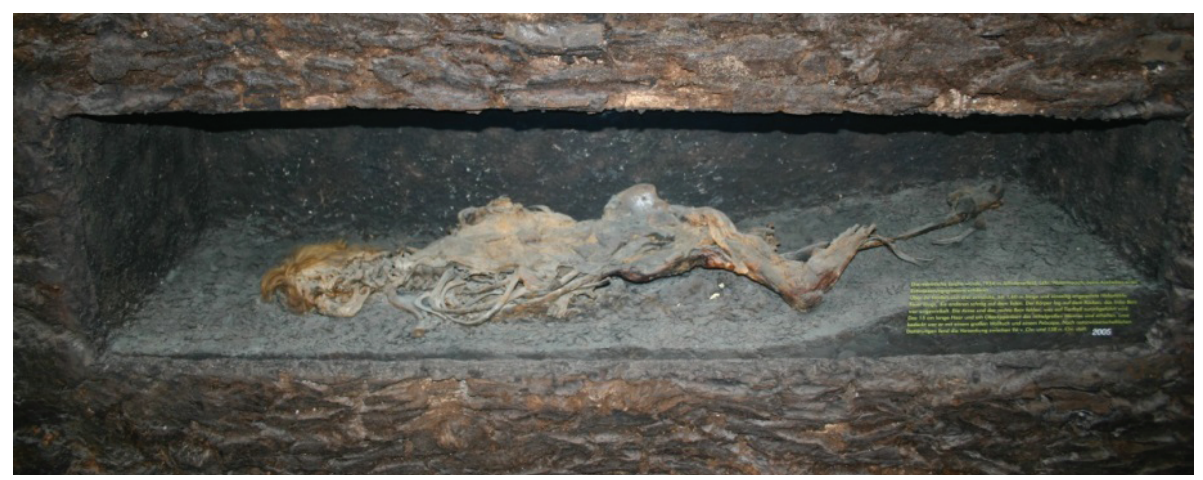

Figure 3. The remains of Jührdenerfeld Man.

Though the only documentation of preservative treatment found for the Jührdenerfeld Man entails slowly drying the body in an unheated room at the State Museum Natur und Mensch (5), some sort of residue is clearly visible on the distal fragments of the left tibia, fibula, and foot bones (Figs. 4a, b, and 5). In 
addition, aluminum foil was used to stuff the body in various places, supporting the head and torso (Fig. 6). Although undocumented, these foil insertion may have been placed there to act as a cushion for the bodily remains or to keep the body level in the exhibit (7).
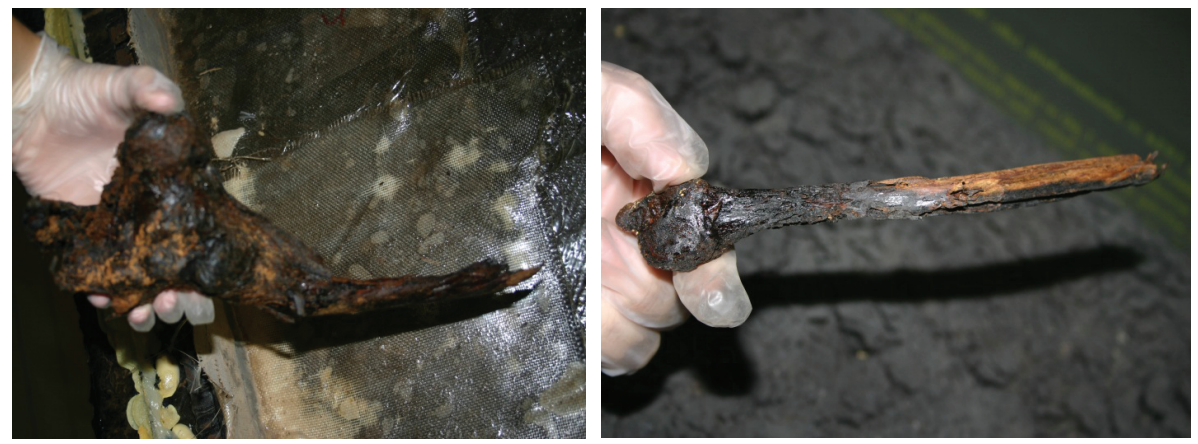

Figures $\mathbf{4 a}$ and $\mathbf{4 b}$. Residue found on the distal left tibia and fibula fragments of Jührdenerfeld Man.

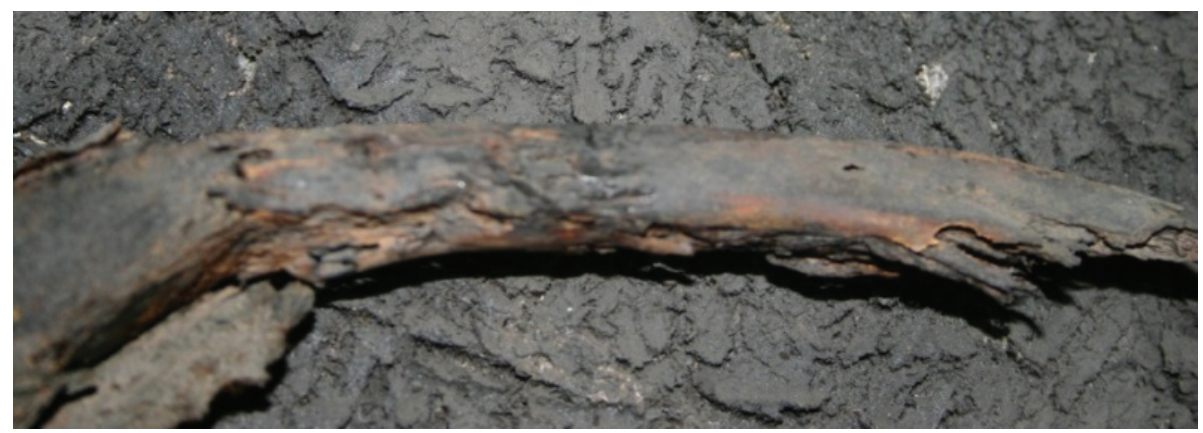

Figure 5. Residue found underneath left distal fibula fragment of Jührdenerfeld Man.

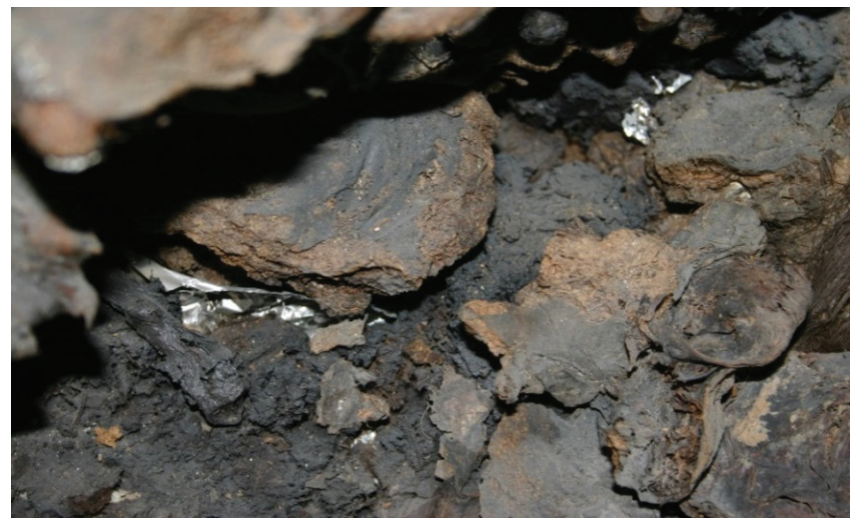

Figure 6. Aluminum foil has been inserted under the body of Jührdenerfeld Man in various places (see red arrows). 


\section{MATERIALS AND METHODS}

An Innov-X Alpha Series analyzer was used to analyze of the bog bodies and their burial environments. Readings taken from various areas of each bog body enabled the most accurate value ranges of concentrations for elements of interest as measured in parts per million (ppm). Each body was scanned three times for 30 second intervals at various pre-determined osteological landmarks to create an average reading for each site. Those averages were then used to create an elemental concentration range for each element of interest and its corresponding bog body. To assess potential bog diagenetic effects, the elements of interest chosen were Copper ( $\mathrm{Cu}$ ), Iron ( $\mathrm{Fe})$, Manganese ( $\mathrm{Mn}$ ), Molybdenum (Mo), Lead $(\mathrm{Pb})$, and Zirconium ( $\mathrm{Zr}$ ). To assess the application of post-discovery preservation procedures, the same elemental concentrations measured to evaluate bog diagenesis were used, along with Cobalt ( $\mathrm{Co})$, Antimony ( $\mathrm{Sb}$ ), and Titanium (Ti). To determine the extent of the effect of bog diagenesis and post-discovery preservative treatment, the concentrations of the elements of interest measured from the bog bodies were also compared to normal human bone elemental concentration levels for those elements.

\section{RESULTS}

To demonstrate statistical significance when comparing elemental ranges between the raised bog bodies and normal human bone, a repeated measures ANOVA with bone locations added as a random effect was used to compute 95\% confidence intervals for the overall mean element values for each of the bodies. We then compared these intervals to normal human bone elemental ranges for each element of interest to test if there is a significant difference among them. Since Mn concentrations for Husbäke Man demonstrated values below the limit of detection, a confidence interval could not be created (Table 1). We also directly compared the concentration ranges for each element of interest to the normal human bone ranges for those elements (Table 2). Each of the elements of interest demonstrates concentration levels and confidence intervals, that are noticeably, if not exceedingly, greater than levels found in normal human bone (Tables 1 and 2). 
Table 1. 95\% Confidence Intervals (Cls) for the mean of Bog Body Elemental Readings

\begin{tabular}{lccc}
\hline Element & Normal HBR $^{*}$ & HM $^{*}$ Cls & JM* Cls $^{*}$ \\
\hline $\mathrm{Cu}$ & $0-19.63$ & $10.16-43.20$ & $15.34-25.83$ \\
\hline $\mathrm{Fe}$ & $100.00-300.00$ & $329.12-774.16$ & $476.58-1092.01$ \\
\hline $\mathrm{Mn}$ & $2.00-10.00$ & $\mathrm{LSD}^{*}$ & $53.14-92.41$ \\
\hline $\mathrm{Mo}$ & $<1.00$ & $13.12-15.16$ & $13.88-15.93$ \\
\hline $\mathrm{Pb}$ & $0-4.00$ & $16.95-22.61$ & $17.73-167.97$ \\
\hline $\mathrm{Zr}$ & $0-5.00$ & $52.30-59.03$ & $54.13-60.93$ \\
\hline
\end{tabular}

${ }^{*}$ HBR = Human Bone Range; HM = Husbäke Man; JM = Jührdenerfeld Man; LSD = Lacking Sufficient Data To Create A Confidence Interval.

Table 2. Elemental Composition of Bog Bodies vs. Normal Human Bone Range

\begin{tabular}{lccc}
\hline Element & Normal HBR & HM ECR $^{*}$ & JM ECR \\
\hline $\mathrm{Cu}$ & $0-19.63$ & $0-87.00$ & $0-33.67$ \\
\hline $\mathrm{Fe}$ & $100.00-300.00$ & $105.33-3261.67$ & $214.67-2273.00$ \\
\hline $\mathrm{Mn}$ & $2.00-10.00$ & $0-70.67$ & $0-79.33$ \\
\hline $\mathrm{Mo}$ & $<1.00$ & $7.50-18.67$ & $8.00-20.00$ \\
\hline $\mathrm{Pb}$ & $0-4.00$ & $10.33-35.00$ & $12.67-383.33$ \\
\hline $\mathrm{Zr}$ & $0-5.00$ & $26.33-70.67$ & $41.33-75.33$ \\
\hline
\end{tabular}

${ }^{*} \mathrm{ECR}=$ Elemental Concentration Range

Reference for data sources (7).

For Jührdenerfeld Man, the particular skeletal areas that demonstrate elevated elemental levels include areas of the left femur, tibia, fibula, calcaneus, talus, medial cuneiform, and cuboid, which correlate with the locations that display some sort of residue. These were compared with areas not believed to have been treated post-discovery on Jührdenerfeld Man. Areas potentially treated with preservatives demonstrated exceedingly high levels of $\mathrm{Cu}, \mathrm{Mn}$, and $\mathrm{Pb}$ when compared to unaffected areas (Table 3).

Table 3. Bog Body Elemental Concentration Ranges of Post-Discovery Preservative Treatment Areas vs. Unaffected Areas

\begin{tabular}{lcc}
\hline Element of Interest & JM PDPT $^{\star}$ Areas ECR & JM Unaffected Areas ECR \\
\hline $\mathrm{Cu}$ & $16.00-116.33$ & $13.00-33.67$ \\
\hline $\mathrm{Fe}$ & $269.67-1636.67$ & $187.33-2273.00$ \\
\hline $\mathrm{Mn}$ & $81.00-368.00$ & $64.00-79.33$ \\
\hline $\mathrm{Mo}$ & $12.00-17.33$ & $8.00-20.00$ \\
\hline $\mathrm{Pb}$ & $112.00-1586.33$ & $12.67-383.33$ \\
\hline $\mathrm{Zr}$ & $46.00-66.00$ & $41.33-75.33$ \\
\hline
\end{tabular}

${ }^{*}$ PDPT $=$ Post-Discovery Preservative Treatment. 
A one-way ANOVA model with bone locations as a random effect was used to compute $95 \%$ confidence intervals of both treated and unaffected bone for Jührdenerfeld Man. These intervals were then compared to normal elemental ranges to determine whether or not they were different from normal human bone. The confidence intervals statistically support the findings that $\mathrm{Cu}, \mathrm{Mn}$, and $\mathrm{Pb}$ all demonstrate higher confidence intervals (Table 4). Additionally, Co also exhibits significantly high levels (Table 5).

Table 4. Cls for Post-Discovery Preservative Treatment Elemental Values

\begin{tabular}{lc}
\hline Element of Interest & JM Cls \\
\hline $\mathrm{Cu}$ & $14.96-85.23$ \\
\hline $\mathrm{Fe}$ & $445.76-1068.07$ \\
\hline $\mathrm{Mn}$ & $91.14-281.97$ \\
\hline $\mathrm{Mo}$ & $12.43-15.18$ \\
\hline $\mathrm{Pb}$ & $212.32-968.50$ \\
\hline $\mathrm{Zr}$ & $46.93-58.67$ \\
\hline
\end{tabular}

Table 5. Additional Elements of Interest with Post-Discovery Preservative Treatment

\begin{tabular}{lcc}
\hline Element of Interest & Normal HCR & JM ECR \\
\hline $\mathrm{Co}$ & $0.01-0.04$ & $39.50-118.33$ \\
\hline $\mathrm{Sb}$ & $0.01-0.6$ & $<$ LOD 139.00 \\
\hline $\mathrm{Ti}$ & $0-40.00$ & $<$ LOD 802.00 \\
\hline
\end{tabular}

Reference for data sources [7].

\section{DISCUSSION AND CONCLUSIONS}

The substantially higher elemental concentrations in all elements of interest suggest that elemental incorporation occurred within the skeletal remains of these two raised bog bodies during interment in the bog. In addition, the exorbitant readings of Co at areas potentially affected by post-discovery preservative treatment with the remains of Jührdenerfeld Man support post-discovery elemental incorporation has occurred. These findings suggest that the residue found with these remains could be the remnants of a metallic adhesive used to rearticulate the damaged bones as well as to keep the remains in place on the mounting board for display.

Applying portable XRFS to the analysis of bog bodies provides valuable information about the interactions between the bog environment and the remains of bog bodies, and can identify post-discovery preservative treatment 
implemented during the conservation process. By assisting in the identification of areas of post-discovery preservation on the bog bodies, portable XRFS can improve comprehension of archival collection history of bog bodies, and can offer the possibility of reversing or lessening the effects of detrimental preservative treatments to the bog bodies.

\section{REFERENCES}

1. Arai T. (2006). Introduction. In: Beckhoff B., Kanngießer B., Langhoff N., Wedell R., Wolff H. (eds), Handbook of Practical X-Ray Fluorescence Analysis. Springer-Verlag Berlin. Heidelberg. 1-26.

2. Asingh P., Lynnerup N. (2007) (eds). Grauballe Man: An Iron Age Bog Body Revisited. Aarhus University Press. Aharus. 351.

3. Bond K. (2007). Reliability of X-Ray Fluorescence for the Quantitative Analysis of Arsenic in Contaminated Leather. Ethnographic Conservation Newsletter, $28,9-10$.

4. Bonizzoni L., Colombo C., Ferrati S., Gargano M., Greco M., Ludwig N. (2011) A critical analysis of the application of EDXRF spectrometry on complex stratigraphies. X-Ray Spectrom, 40, 4, 247-253.

5. Fansa M., Both F. (2011). Faszination Moorleichen. Landesmuseum Natur und Mensch. Philipp von Zabern. Oldenburg.

6. Fansa M., Jopp E., Pueschel K. (2010). Das Kind aus der Esterweger Dose. Dokumentation einer aussergewoehnlichen Skelett-Moorleiche. Schriftum des Landesmuseums Natur und Mensch, 74.

7. Granite G. (2012). Portable X-Ray Fluorescence Spectroscopy and its Research Applications to Northern European Bog Bodies. Ph.D. dissertation, Department of Anthropology, State University of New York at Buffalo. (UMI No. AAT 11932).

8. Granite G., Bauerochse A. (2010a). Mobile X-Ray Fluorescence Spectroscopy (XRF) Investigations on the Child from the Esterweger Dose - Preliminary Results. In: Fansa M., Jopp E., Püschel K. (eds), Das Kind aus der Esterweger Dose. Dokumentation einer außergwöhnlichen Skelett-Moorleiche. Schriftum des Landesmuseums Natur und Mensch. Isensee-Verlag Oldenburg. Oldenburg, 74, 69-73.

9. Granite G., Bauerochse A. (2010b). X-Ray Fluorescent Spectroscopy and its Application to the Analysis of Kayhausen Boy. In: Fansa M., Jopp E., Püschel K. (eds), Der Junge von Kayhausen und die Haut aus dem Bareler Moor: Neueste Untersuchungsergebnisse aus Museumsjournal Natur und Mensch. IsenseeVerlag Oldenburg. Oldenburg, 6, 95-102. 
10. Granite G., Bauerochse A. (2013a). Analysis of the Peiting Woman Using Portable X-Ray Fluorescence Spectroscopy. Chronika. The Institute for European and Mediterranean Archaeology. Volume 3.

11. Granite G., Bauerochse A. (2013b). The Application of Portable X-Ray Fluorescence Spectroscopy to the Analysis of the Niedermoortorf (Gnattenbergwiesen) Bog Body. Anthropology: Bachelors to Doctorates. Volume 1, Issue 1.

12. Granite G., Bauerochse A. (In press). The Research Applications of Portable X-Ray Fluorescence Spectroscopy on the Dental and Skeletal Remains of Bernuthsfeld Man. In: Bär H.J., Püschel K., Schultz M. (eds), Die Moorleiche von Bernuthsfeld. Ergebnisse des 1. Bernie-Symposiums im Ostfriesischen Landesmuseum Emden, 18.11.2011. Materialhefte zur Ur- und Frühgeschichte Niedersachsens (in Vorb.).

13. Katzenberg M.A. (1984). Chemical analysis of prehistoric human bone from five temporally distinct populations in southern Ontario. Ph.D. dissertation, Department of Anthropology, University of Toronto. (UMI No. AAT NK62106).

14. Kenna T.C., Nitsche F.O., Herron M.M., Mailloux B.J., Peteet D., Sritrairat S., Sands E., Baumgarten J. (2011). Evaluation and calibration of a Field Portable X-Ray Fluorescence spectrometer for quantitative analysis of siliciclastic soils and sediments. J Anal Atom Spectrom, 26, 2, 395-405.

15. Pieper P. (2003). Peat Bog Corpses. In: Bauerochse A., Haßmann H. (eds), Peatlands, archaeological sites - archives of nature - nature conservation - wise use. 107-114.

16. Pieper P., Behre K.-E., Moehlenhoff P., Parpatt P.M., Schuebel F., Schuebel J. (1999). Moorleichen. In: Fansa M. (ed.), Weder See noch Land. Moor - eine verlorene Landschaft. Schr. Staatl. Mus. Naturkunde Oldenburg, 10, 1, 62-80.

17. Polikreti K., Murphy J.M.A., Kantarelou V., Karydas A.G. (2011). XRF analysis of glass beads from the Mycenaean palace of Nestor at Pylos, Peloponnesus, Greece: new insight into the LBA glass trade. J Archaeol Sci, 38, 11, 2889-2896.

18. Somervaille L.J., Nilsson U., Chettle D.R., Tell I., Scott M.C., Schutz A., Mattsson S., Skerfving S. (1989). In vivo measurements of bone lead - a comparison of two X-ray fluorescence techniques used at three different bone sites. Phys Med Biol, 34, 12, 1833-1845.

19. van der Plicht J., van der Sanden W.A.B., Aerts A.T., Streurman H.J. (2004). Dating bog bodies by means of ${ }^{14} \mathrm{C}$-AMS. J Archaeol Sci, 31(4), 471-491.

20. van der Sanden W.A.B. (1996). Through nature to eternity - the bog bodies of northwest Europe. Drents Museum / Batavian Lion International. Amsterdam. 200.

21. Zoeger N., Wobrauschek P., Streli C., Pepponi G., Roschger P., Falkenberg G., Osterode W. (2005). Distribution of $\mathrm{Pb}$ and $\mathrm{Zn}$ in slices of human bone by synchrotron m-XRF. X-Ray Spectrom, 34, 2, 140-143. 
22. Zoeger N., Streli C., Wobrauschek P., Jokubonis C., Pepponi G., Roschger P., Hofstaetter J., Berzlanovich A., Wegrzynek D., Chinea-Cano E., Markowicz A., Simon R., Falkenberg G. (2008). Determination of the elemental distribution in human joint bones by SR micro XRF. X-Ray Spectrom, 37, 1, 3-11.

\section{Address for correspondence:}

Dr Guinevere Granite

Maryland State Anatomy Board, Anatomical Services Division

School of Medicine

University of Maryland, Baltimore

655 West Baltimore Street

BRB B-024

Baltimore, Maryland, 21201

USA 